\title{
Publisher Correction: Adaptive modulation of brain hemodynamics across stereotyped running episodes
}

Antoine Bergel (1D, Elodie Tiran, Thomas Deffieux, Charlie Demené, Mickaël Tanter \& Ivan Cohen (1)

Correction to: Nature Communications https://doi.org/10.1038/s41467-020-19948-7, published online 3 December 2020.

The original HTML version of this Article was updated shortly after publication because the previous HTML version contained errors in the links to Supplementary Movies 1-6 and the Reporting Summary. These have been corrected in the HTML version of the article.

Published online: 21 December 2020

\section{Additional information}

Supplementary information is available for this paper at https://doi.org/10.1038/s41467-020-20571-9.

(c) (1) Open Access This article is licensed under a Creative Commons Attribution 4.0 International License, which permits use, sharing, adaptation, distribution and reproduction in any medium or format, as long as you give appropriate credit to the original author(s) and the source, provide a link to the Creative Commons license, and indicate if changes were made. The images or other third party material in this article are included in the article's Creative Commons license, unless indicated otherwise in a credit line to the material. If material is not included in the article's Creative Commons license and your intended use is not permitted by statutory regulation or exceeds the permitted use, you will need to obtain permission directly from the copyright holder. To view a copy of this license, visit http://creativecommons.org/licenses/by/4.0/.

() The Author(s) 2021 